\title{
FORECAST OF USING NEURAL NETWORKS IN THE TOURISM SECTOR
}

\author{
Miroslav Karahuta, ${ }^{1}$ Peter Gallo, ${ }^{2}$ Daniela Matušíková, ${ }^{3}$ Anna Šenková, ${ }^{4}$ \\ Kristína Šambronská ${ }^{5}$
}

\begin{abstract}
The paper addresses the issue of management decision-making using artificial neural networks and their application in hotel management. Today, the development of tourism is of great importance and plays a very important role in the development of national economy. Balanced ranking and prediction model using financial and non-financial indicators with the application of artificial intelligence, allows us to reach a high level of effectivity and accuracy in evaluation of the financial and non-financial health of companies operating in this segment. This approach improves the manager's ability to understand complex contexts and make better decisions for further development. It also brings new managerial and scientific point of view of an in-depth analysis of the performance of these facilities. It can help the development of tourism in terms of the application of modern management techniques built on scientific principles and thereby better integrate science and practice.
\end{abstract}

JEL Classification Numbers: C45, Z32; DOI: http://dx.doi.org/10.12955/cbup.v5.928

Keywords: Prediction models, financial health, neural networks, management, tourism.

\section{Introduction}

Tourism development has great importance and plays a significant role in the development of national economies (Šenková and Šambronská, 2014; Council, 2016). Therefore, the efforts of each country are heading to assist in the development of this industry effectively. Management, economics and application of modern methods of economics and management have very important role in this development and thus equally important is managerial decision making. The ability to decide optimally is one of the most crucial parts of hotel manager's everyday job (O'Halloran, 2015). There are several methods that can be used in the field of managerial decision making. Many methods are based on an assessment of the performance of these businesses using the methods of financial analysis, prediction models, Economic Value Added or the methodology of the business performance analysis based on financial (Horváthová and Mokrišová, 2014) and non-financial indicators - Balanced Scorecard (Ivanickova et al., 2016). All these methods provide information to the optimal decision making by managers and to better controlling of these organizations. From modern economics models that can play a major role in the future, the management decision-making methods based on classification and prediction using artificial neural networks (ANN) are the most promising.

Artificial neural networks are one of the modern trends in assessment of the financial and nonfinancial health of the business. They are particularly suitable when part of the decision-making processes depends on coincidence and/or deterministic dependency. They are therefore suitable for modeling and exploration of complex, single, often irreversible strategic management decisions (Hanne, 1997).

During analytical phase of research, we have conducted many experiments with popular conventional models like Tafler model (Taffler and Tisshaw, 1977), Altman Z Score (Altman, 2013), Springate model (Springate et al, 1983) and many more (Beerman, 1976; Ohlson, 1980; Zmijewski, 1984; Kralicek and Spal, 1993; Hajdu and Virág, 2001; Neumaier and Neumaierová, 2005). Almost no commonly used model is optimal for tourism and specifically for hotel management.

Principal problems of conventional models were identified, such as their static nature and reliance on the principles of market behavior, which assumes a certain rational behavior of the consumer. Many models focus only on the financial side of the business, which is optimal for production type company, but not so for customer and service based businesses. Therefore, the presented model had to overcome these disadvantages and at the same time, be a convenient and efficient tool for managers.

\footnotetext{
${ }^{1}$ Mgr. Miroslav Karahuta, Faculty of Management, Prešov University in Prešov, karahuta@gmail.com

2 doc. Ing. Peter Gallo, CSc., Faculty of Management, Prešov University in Prešov, peter.gallo@unipo.sk

${ }^{3}$ PhDr. Daniela Matuš́ková, PhD., Faculty of Management, Prešov University in Prešov, daniela.matusikova@unipo.sk

${ }^{4}$ Ing. Anna Šenková, PhD., Faculty of Management, Prešov University in Prešov, anna.senkova@unipo.sk

${ }^{5}$ Ing. Kristína Šambronská, PhD., Faculty of Management, Prešov University in Prešov, kristina.sambronska@unipo.sk
} 


\section{Design of model}

Designing of model based on the artificial neural network requires multiple steps and decisions to be made. The most important are input and output neurons and their number. Based on chosen topology, there are different types of hidden layers of neurons, their number and interconnections. Using appropriate configuration of ANN, activation functions and learning algorithm, we can create a network capable of analyzing and classifying health of companies in the accommodation sector in tourism.

However, technology is not enough. Deep analysis of accommodation sector was an essential part of this research. Without a deep understanding of the sector, there is a big probability of incorrect results - GIGO (Garbage In, Garbage Out). Learning system learns only from data provided.

\section{The research samples}

For this research, the basic research set of businesses operating in hotel services in Slovakia was created. Businesses were selected based on SK NACE, specifically Section I - Accommodation and food services, Division 55 - Accommodation and Group 551 - Hotels and similar accommodation. Time vector was 2009 - 2015. According to the portal "Index podnikatela", (www.indexpodnikatela.sk) there were 1,652 businesses under the category SK-NACE 55.1. Subjects in this group consisted of business entities that are registered in the Commercial Register of the Slovak Republic and have submitted financial statements to the commercial register. This research group was separated into two groups. First one, labeled as ZS1, contained only healthy companies. The second group, marked as ZS2, contained companies in liquidation or companies which undergo the healing process. ZS1 group consisted of 1,514 companies, ZS2 group consisted of 138 companies. By using simple random sampling, the final research samples were created (S1 from ZS1 and S2 from ZS2). To optimize and maintain the objectivity of the results, companies that own more than one property were eliminated due to the unavailability of financial statements separately for each accommodation company.

For necessary verification of the functionality of the model, in addition to mechanisms that are part of the ANN, six companies were selected: two healthy companies of the group S1, two companies in bankruptcy/liquidation from the group S2 and two artificially created enterprises - one healthy and one problematic. Both artificially designed companies had been set up as real as possible to represent their category. These companies were not included in the data files intended for training, validation and testing ANN. It was applied only for final verification and comparison. An overview of all companies and their designations are shown in Table 1.

\begin{tabular}{|l|l|l|l|}
\hline \multicolumn{4}{|l|}{ Table 1: Basic profiles of test companies } \\
\hline ID & Category & Class & State \\
\hline SZ1 & Hotel & $* * * *$ & healthy \\
\hline SZ2 & Hotel & $* * *$ & healthy \\
\hline SK1 & Pension & $* *$ & bankruptcy \\
\hline SK2 & Congress hotel & $* * *$ & bankruptcy \\
\hline SSZ & Hotel & $* * *$ & simulated healthy \\
\hline SSK & Hotel & $* * *$ & simulated bankruptcy \\
\hline Source: Authors
\end{tabular}

\section{Data sources and input variables}

Hotel and tourism business can be characterized as a business in an unstable environment with some level of risk and uncertainty. Changes in the market are swift and quite frequent. The common problem is also the rationality of customer behavior and changing trends. Therefore, the replacement of staff in this process is difficult, despite the intensive development of advanced technologies and management practices. The proposed model is designed to be a helpful tool for the manager, not his replacement. It helps managers to focus on the core of the business. To fix issues with traditional models mentioned in the introduction and to create a practical and precise model, we had focused on financial but also non-financial data and selected most valuable for hotel analysis and benchmarking. 
We gathered information from multiple sources separated into two main groups:

Financial data: Register of Financial Statements, Commercial Bulletin, Trade Register, Statistical Office of the Slovak Republic, Financial Administration Slovak Republic, Public Procurement Office, Social Insurance Agency in Slovakia, Insurance.

Non-financial data: Association of Hotels and Restaurants of the Slovak Republic, Association of Tourism of the SR, Hotrec, Booking.com, TripAdvisor, STB, UNWTO, WTTC, Eurostat, European Travel Commission, Eurobarometer and the hotel websites.

After analyzing of every type of information gathered, the input variables were selected. They were divided into three groups: Financial (standard and reliable indicators of financial analysis and prediction models), Non-financial (relevant information specifying property) and Organizational (information specifying company). Input variables, their category, type and defined ID for clarity of research are shown in Table 2.

\begin{tabular}{|c|c|c|c|}
\hline Category & ID & Name & Type \\
\hline \multirow{11}{*}{ Financial } & VF1 & Receivables turnover period & $\mathrm{R}$ \\
\hline & VF2 & Commitments turnover period & $\mathrm{R}$ \\
\hline & VF3 & Inventory turnover period & $\mathrm{R}$ \\
\hline & VF4 & Overcapitalisation degree & $\mathrm{R}$ \\
\hline & VF5 & Total debt & $\mathrm{R}$ \\
\hline & VF6 & Short-term debt & $\mathrm{R}$ \\
\hline & VF7 & Return on equity & $\mathrm{R}$ \\
\hline & VF8 & Return on sales & $\mathrm{R}$ \\
\hline & VF9 & Total liquidity & $\mathrm{R}$ \\
\hline & VF10 & Current liquidity & $\mathrm{R}$ \\
\hline & VF11 & Year & I \\
\hline \multirow{2}{*}{ Organizational } & PO1 & Year of foundation & I \\
\hline & $\mathrm{PO} 2$ & Size of organization & $\mathrm{C}$ \\
\hline \multirow{8}{*}{ Non-financial } & PN1 & Class & $\mathrm{C}$ \\
\hline & PN2 & Category & $\mathrm{C}$ \\
\hline & PN3 & Number of rooms & I \\
\hline & PN4 & Price & $\mathrm{R}$ \\
\hline & PN5 & Location type & $\mathrm{C}$ \\
\hline & PN6 & Seasonality & B \\
\hline & PN7 & Booking.com - score & $\mathrm{R}$ \\
\hline & PN8 & Tripadvisor - score & $\mathrm{R}$ \\
\hline
\end{tabular}

\section{Model mechanics}

Model mechanics can be simplified to the following basic steps: input of variables, variables processing, application of artificial neural networks and display output data. The main function of the proposed model is to classify health of the hotel. For this purpose, the MLP (Multi-Layer Perceptron) feedforward artificial neural network using backward propagation of errors training method was chosen. ANN model contains 21 input neurons. Each input neuron represents one variable. The model includes one hidden layer, and the output layer contains one neuron.

\section{The model output}

The output of proposed ANN is a real number in the range of $\langle 0 ; 1\rangle$ for each company per year. This one number provides immediate information about the state of business health. The 1 represents a healthy enterprise, 0 accounts for the troubled company. The turning point is in the middle - the value of 0.5 .

The main output of the model is Hotel Report which processes and shows multiple financial and nonfinancial data in textual and multiple visual formats. The most important part is the result of ANN, its interpretation and multiple recommendations for the manager. Diagram of the model is shown in Figure 1. 


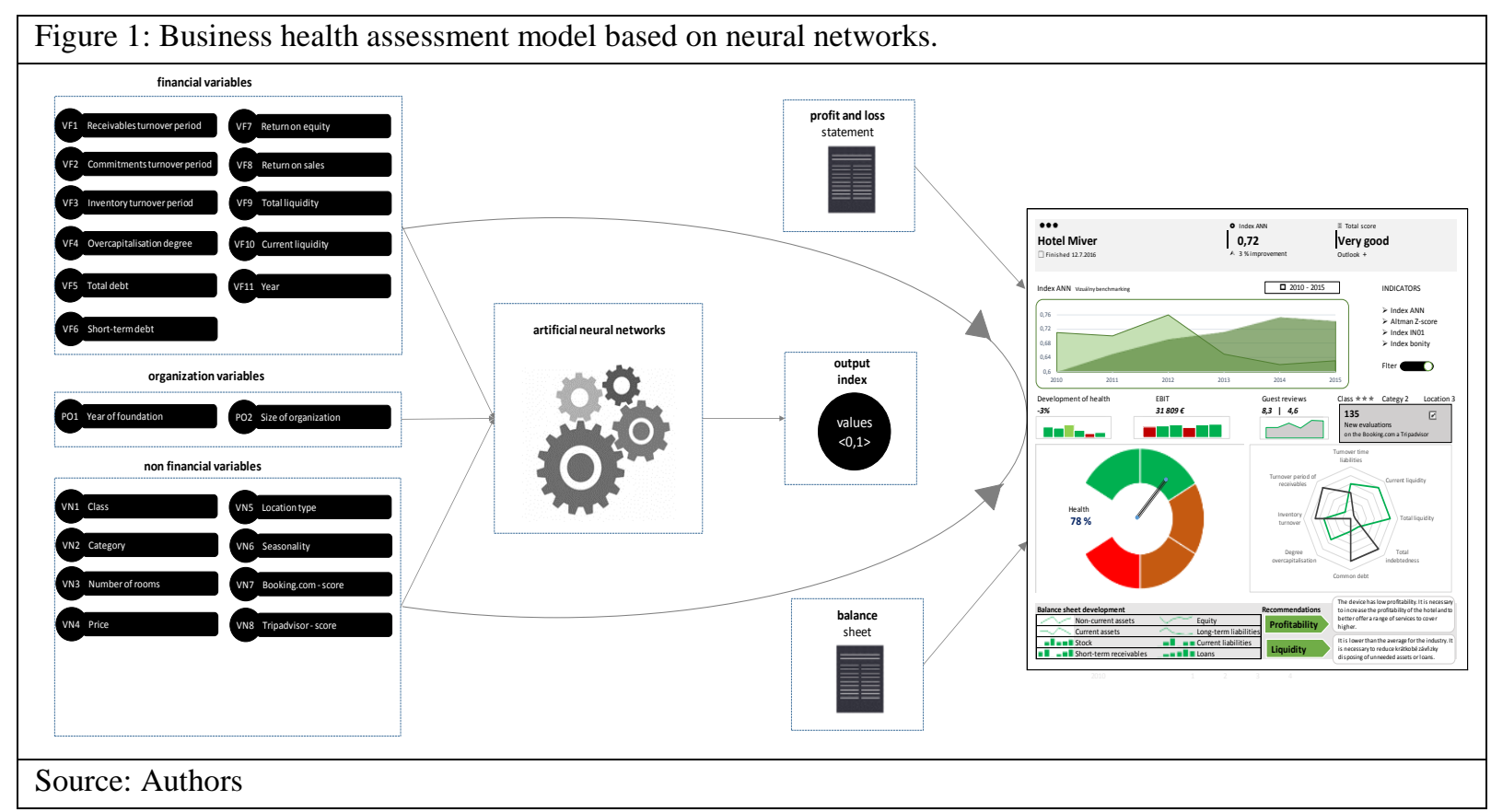

\section{Results}

During experimental phase, we have analyzed multiple types and configuration of the artificial neural network. The final testing configurations consisted of 9-18 hidden neurons, 10\%-20\% of data separated for testing and 3 different training algorithms (Levenberg-Marquardt, Bayesian Regularization a Scaled conjugate gradient).

Final configuration consisted of 12 hidden neurons, $70 \%$ of data for training, $15 \%$ for validation and $15 \%$ for testing. Training algorithm was Levenberg-Marquardt. The progress of learning is shown in Figure 2. Deviations and regressions are listed in Table 3.

\begin{tabular}{|l|c|c|c|}
\hline \multicolumn{4}{|l|}{ Table 3: Deviations and regressions of ANN model } \\
\hline Phase & Number of samples & MSE & R \\
\hline Training & 621 & 0.0084 & 0.908 \\
\hline Validation & 132 & 0.023 & 0.784 \\
\hline Testing & 132 & 0.0242 & 0.761 \\
\hline
\end{tabular}

Source: Authors

Figure 2: ANN learning progress

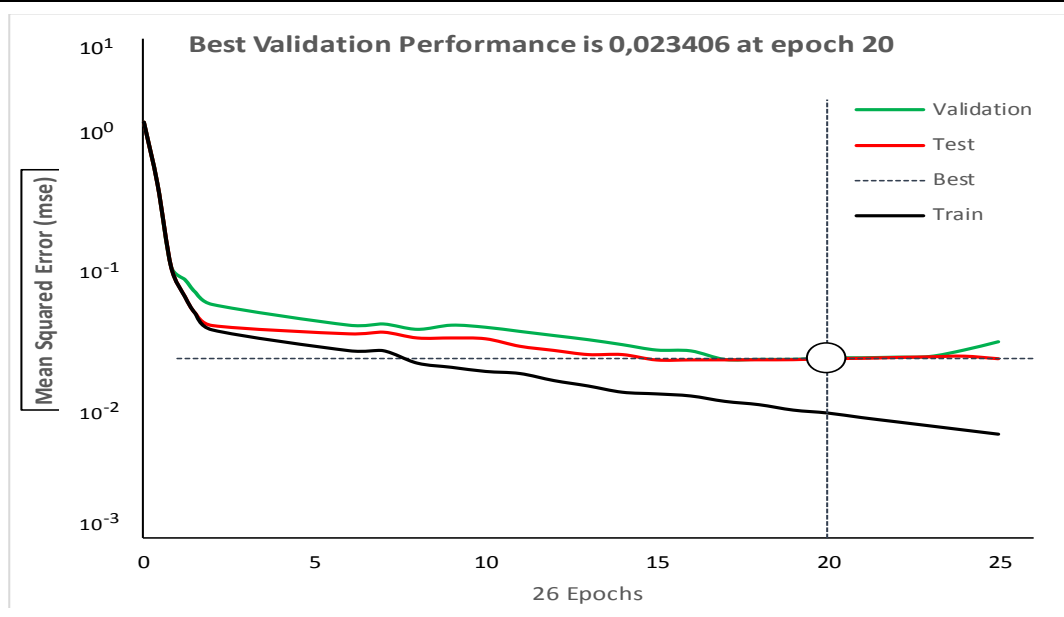

Source: Authors 
We had selected six companies for separate testing and validation of network. To avoid overfitting, these companies were not included in data set for ANN. This verification of an ANN model brought satisfactory results. Comparison of expected results and actual results of ANN are shown in Table 4.

\begin{tabular}{|l|c|c|}
\hline \multicolumn{3}{|l|}{ Table 4: Comparison of expected classification and ANN results. } \\
\hline ID & Hypothesis & Results \\
\hline SZ1 & healthy & healthy \\
\hline SZ2 & healthy & healthy \\
\hline SK1 & problematic & problematic \\
\hline SK2 & problematic & healthy \\
\hline SSZ & healthy & healthy \\
\hline SSK & problematic & problematic \\
\hline Source: Authors & & \\
\hline
\end{tabular}

Neural network wrongly classified SK2 company as healthy, although it was twice in liquidation. However, a closer analysis of the company showed that the reasons for liquidation are questionable and it did not have to be caused by bad state or financial results of the hotel. Because, after liquidation, the property was taken over by another company with a very similar name and ownership structure.

\section{Conclusion}

In conclusion, we would like to point out the indicators that are relevant and applicable in models for classification and prediction of the state of the organization. There are many indicators that may be applicable in models evaluating the condition of the property. Controlling in tourism offers a whole group of quality indicators, but for their calculation, the non-public information is often needed. The most important variables characterizing the property are the class, category, price, customer satisfaction, service quality, promotion and portals like Trip advisor and Booking.com. These portals have brought one of the most significant changes in the approach to the client, so it is important to take them into account when analyzing the state of the property.

Despite highlighting the importance of the analysis of non-financial factors, we do not expect their direct impact on the financial health of the company. Their importance and significance are increasing in combination with financial indicators and other non-financial indicators. Each category and class of accommodation property have an existing target group of customers. Problems of inappropriate choice of category, class or other nonfinancial variable arise from their improper combinations (for example, $5^{*}$ hotel in unattractive and economically less developed areas).

The research has shown that the model built upon the artificial neural network using a complex business analysis in the context of the internal and external factors is more accurate than conventional models. To confirm this hypothesis, we have chosen randomly selected companies that were previously labeled as healthy or unhealthy. These data were not included in the data set intended for the Artificial Neural Network training. Then, we have calculated the classification of companies using conventional methods as well as the proposed model. Results were statistically compared with real estate. For this purpose, the Pearson $\chi^{2}$ test was used. Summary of the results is shown in Table 5. Assumptions and hypothesis were confirmed. All conventional models were significantly different from the real situation. In the case of the proposed model, the statistical discrepancy was not confirmed. This does not prove that conventional models are wrong or unusable. They are supposed to be used in sectors they were created for (mostly manufacturing companies). Despite this, many authors used them as universal models.

\begin{tabular}{|c|c|c|c|}
\hline $\mathbf{A N N}$ & Pearson $\chi^{2}: .382114, p=.536474$ & Taffler & Pearson $\chi^{2}: 4.91860, p=.026569$ \\
\hline Altman & Pearson $\chi^{2}: 18.4314, p=.000018$ & IN01 & Pearson $\chi^{2}: 29.4185, \mathrm{p}=.000000$ \\
\hline Springate & Pearson $\chi^{2}: 46.3404, p=.000000$ & & \\
\hline
\end{tabular}


We can conclude that not only in the future but already today, artificial neural networks can play a significant role in modern methods of management of accommodation properties in tourism.

\section{Acknowledgements}

The paper was created as part of the scientific research project KEGA no. 020PU-4/2015 (Creating multimedia web documents for e-learning and improving the quality of knowledge managers and students) and project VEGA no. 1/0791/16 (Modern approaches to improving enterprise performance and competitiveness using the innovative model - Enterprise Performance Model to streamline Management Decision-Making Processes).

\section{References}

Altman, E. I. (2013). Predicting Financial Distress Of Companies: Revisiting The Z-Score And Zeta ${ }^{\circledR}$ models. V A. R. Bell, C. Brooks, \& M. Prokopczuk, Handbook of Research Methods and Applications in Empirical Finance Cheltenham: Edward Elgar Publishing. 428-456. doi:10.4337/9780857936097.00027

Beerman, K. (1976). Possible Ways to Predict Capital Losses with Annual Financial Statements. University of Dusseldorf.

Council, W. T. (2016). Travel \& Tourism - economic impact 2016 world. WTTC.

Hajdu, O., \& Virág, M. (2001). A Hungarian model for predicting financial. Társadalom és gazdaság Közép- és KeletEurópában / Society and Economy in Central and Eastern Europe, 28-46.

Hanne, T. (1997). Decision Support for MCDM That Is Neural Network-Based and Can Learn. In P. Clímaco (eds) Multicriteria Analysis. Berlin: Springer Berlin Heidelberg. 401-410. doi:10.1007/978-3-642-60667-0_38

Horváthová, J., \& Mokrišová, M. (2014). Diagnostika výkonnosti podnikov s aplikáciou moderných metód hodnotenia finančnej výkonnosti [Diagnosing performance of businesses with the application of modern methods of evaluating financial performance]. Economics Management Innovation, 6(3), 46-60.

Ivanickova, M., Mihalcova, B., \& Gallo, P. (2016). Assessment of companies' financial health: Comparison of the selected prediction models. Actual Problems of Economics, 180(6), 383-391.

Kralicek, P., \& Spal, J. (1993). Základy finančního hospodaření [Basics of financial management]. Praha: Linde.

Neumaier, I., \& Neumaierová, I. (2005). Index IN 05. Sborník př́spěvků mezinárodní vědecké konference „Evropské finanční systémy“. Brno: Ekonomicko-správní fakulta Masarykovy university v Brně. 143-148.

O’Halloran, R. (2015). Strategies for Decision Making. Retrieved from Hotel Business Review: http://hotelexecutive.com/business_review/2146/strategies-for-decision-making

Ohlson, J. A. (1980). Financial Ratios and the Probabilistic Prediction of Bankruptcy. Journal of Accounting Research, 109131. doi:10.2307/2490395

Šenková, A., \& Šambronská, K. (2014). Hotelový a reštauračný manažment [Hotel and restaurant management.]. Prešov: Bookman.

Springate, G., Turgut, V., \& Sands, E. (1983). Predicting Business Failures. CGA Magazine, 24-27.

Taffler, R., \& Tisshaw, H. (1977). Going, going, gone - four factors which predict. Accountancy, 50-54.

Zmijewski, M. E. (1984). Methodological Issues Related to the Estimation of Financial Distress Prediction Models. Journal of Accounting Research, 59-82. 